\title{
Suspended sediments - associated water quality elements
}

\author{
SEYED HAMIDREZA SADEGHI \& HIVA YAGHMAEI
}

Department of Watershed Management Engineering, Faculty of Natural Resources, Tarbiat Modares University (TMU), Noor46417-76489, Mazandaran Province, Iran

sadeghi@modares.ac.ir

\section{INTRODUCTION}

The detrimental impact of sediment and associated pollutants on water quality is widely acknowledged for many water sources (Rickson 2014). There is increasing recognition that fine sediment represents an important diffuse source pollutant in waters surface (Walling and Collins 2008). In many cases, toxic substances can be absorbed by sediment particles and then transported to other areas. Studying the quantity, quality, and characteristics of sediments in the stream helps scientists and engineers to determine the sources and evaluate the impact of the pollutants on the aquatic environment. Recognizing the role of suspended sediment (SS) in the transportation of major elements from land to rivers is necessary (Chau 2006). In this study we tried to evaluate the role of SS in transportation of calcium, magnesium, nitrogen and phosphorus to the river. We also estimated the percentages of each of the above mentioned elements which carried on SS to the total amounts transported as dissolved and particulate forms. The results therefore help managers and decision makers to properly designate control strategies in the study area.

\section{MATERIALS AND METHODS}

The study area was the main river of the Educational and Research Forest of Tarbiat Modares University located in the north of Iran. The study watershed comprises around some 50000 ha extending between longitudes $51^{\circ} 48^{\prime} 8^{\prime \prime}$ to $59^{\circ} 49^{\prime} 40^{\prime \prime}$ East and latitudes $36^{\circ} 24^{\prime} 4^{\prime \prime}$ to $36^{\circ} 32^{\prime} 33^{\prime \prime}$ North. The polyethylene vessels selected for sample collection were washedby acid to eliminate any potential pollution (Ahearnet al. 2005) and the 2litre-samples were obtained through depth integration (Hsu et al. 2007). The samples were collected semi-weekly under different hydrological conditions. One litre of sample was then filtered through a $0.45 \mathrm{~lm}$ Watmann filter (42) for measuring SS. The weights of the particulate and dissolved parameters were measured by scales with an accuracy of 1:1000 by standard methods (Kiteca and Jai 2005, Mitchell et al.2005). The percentage of each element transferred in dissolved or particulate form was calculated and consequent comparisons were analysed by using SPSS16 software.

\section{RESULTS AND CONCLUSION}

The results of the statistical analyses of the study variables are shown in Table 1 . The maximum contents of $\mathrm{Ca}, \mathrm{P}$ and $\mathrm{Mg}$ were carried contemporary with the mine exploitation period and flood occurrence. This finding agrees with Zhang et al. (2007) and Hunter and Walton (2008) who believed in the high effectiveness of hydrological condition on the transportation rates of water pollutants with suspended sediment. However, variation of $\mathrm{N}$ did not follow the SS trend in the study area which verified the high potential of $\mathrm{N}$ for transport in dissolved form that has been reported for forest areas. Although the potential for $\mathrm{N}$ loss in overland and subsurface flow increases with soil nutrient concentration, it also depends on many other factors (McDowell et al. 2004). Considering the result of this study has showed that SS is the most important factor for the transfer of phosphorus which is the most significant water quality parameter in sea plants nutrition. This result is confirmed by Drewry et al. (2005) in the Moruya and Tuross River watershed in Australia. We found that the greatest amount of phosphorus was transferred in particulate form during flood events. This is due to accumulation of phosphorus on the soil surface and its dependency on soil erosion and sedimentation. It is confirmed by the results of Zhang et al. (2007) in Japan on increase of phosphorus during flood events. It was concluded that the device used in this study could not identify particulate Nitrogen; this result concurs with Esberg et al. (2004). 
This is due to the presence of forest which caused transformation of Nitrogen to nitrate salt and transfer of Nitrogen in dissolved form as reported by Walling (2005) for transfer of large amounts of Nitrogen in solution. Soil erosion with transfer of SS from the soil surface to rivers can lead toincrease of the dissipation of nutrients from the soil and also enhance water pollution. Somura et al. (2012) confirmed the relationship between phosphate and SS in the Hii River basin in Japan, and Hsu et al. (2009) emphasized that during flood, the concentration of pollution increased rapidly. According to Table 2, transfer of the elements by SS during the mining period is of secondary importance. The results of the present study have revealed the importance of proper environmental management to control soil erosion and transfer of SS as a carrier of pollutants into the rivers.

Table 1 Mean concentrations $\left(\mathrm{mg} \mathrm{L}^{-1}\right)$ of elements transferred to the river as dissolved and suspension under different hydrological conditions.

\begin{tabular}{lllll}
\hline Elements & Transportation form & Base flow & Flood & Mine exploitation \\
\hline Phosphorus & Dissolved & $0.09 \pm 0.05$ & $0.25 \pm 0.03$ & $0.15 \pm 0.03$ \\
& Particulate & $0.7 \pm 0.21$ & $51.95 \pm 21.4$ & $17.82 \pm 11.46$ \\
Calcium & Dissolved & $44.14 \pm 1.07$ & $47.97 \pm 4.2$ & $51.00 \pm 5.04$ \\
& Particulate & $5.21 \pm 0.91$ & $833.5 \pm 481.5$ & $146.65 \pm 119.15$ \\
Magnesium & Dissolved & $30.97 \pm 1.30$ & $37.63 \pm 3.50$ & $35.63 \pm 3.10$ \\
& Particulate & $3.90 \pm 0.92$ & $318.24 \pm 179.57$ & $141.76 \pm 103.99$ \\
Nitrogen & Dissolved & $0.33 \pm 0.34$ & $0.34 \pm 0.10$ & $0.19 \pm 0.05$ \\
& Particulate & No data & No data & No data \\
\hline
\end{tabular}

Table 2 Percentages of qualitative parameters transferred as particular form to the river under different hydrological conditions.

\begin{tabular}{|c|c|c|c|c|}
\hline Variable & State & Maximum & Minimum & Mean \\
\hline Nitrate $\left(\mathrm{mg} \mathrm{L}^{-1}\right)$ & $\begin{array}{l}\text { Natural } \\
\text { Flood } \\
\text { Mine exploitation }\end{array}$ & $\begin{array}{l}34.00 \\
98.02 \\
92.00\end{array}$ & $\begin{array}{l}0.36 \\
0.47 \\
9.37\end{array}$ & $\begin{array}{l}8.32 \\
39.75 \\
37.29\end{array}$ \\
\hline Magnesium $\left(\mathrm{mg} \mathrm{L}^{-1}\right)$ & $\begin{array}{l}\text { Natural } \\
\text { Flood } \\
\text { Mine exploitation }\end{array}$ & $\begin{array}{l}47.20 \\
97.10 \\
96.80\end{array}$ & $\begin{array}{l}0.03 \\
13.51 \\
5.66\end{array}$ & $\begin{array}{l}9.35 \\
35.11 \\
44.47\end{array}$ \\
\hline Phosphorus (mg L ${ }^{-1}$ ) & $\begin{array}{l}\text { Natural } \\
\text { Flood } \\
\text { Mine exploitation }\end{array}$ & $\begin{array}{l}99.13 \\
99.8 \\
99.6\end{array}$ & $\begin{array}{l}10.25 \\
98.00 \\
71.40\end{array}$ & $\begin{array}{l}69.58 \\
99.12 \\
90.58\end{array}$ \\
\hline Calcium (mg L-1) & $\begin{array}{l}\text { Natural } \\
\text { Flood } \\
\text { Mine exploitation }\end{array}$ & $\begin{array}{l}34.00 \\
98.02 \\
92.00\end{array}$ & $\begin{array}{l}0.36 \\
0.47 \\
9.37\end{array}$ & $\begin{array}{l}8.32 \\
39.75 \\
37.29\end{array}$ \\
\hline
\end{tabular}

\section{REFERENCES}

Ahearn, A.S., et al. (2005) Land use and land cover influence on water quality in the last free-flowing river draining the western Sierra Nevada, California. Journal of Hydrology 313, 234-247.

Chau, KW. (2006) Persistent organic pollution characterization of sediments in Pearl River estuary. Chemosphere 64, 1545-1549.

Drewry, J. et al. (2005) The role of soil regolith properties, river suspended sediment and nutrient concentration during storm event in the Moruya and Tuross Catchments, NSW. Regolith, Ten Years of CRC LEME 78-82.

Esberg, C. et al. (2004)Microbial responses to P addition in six South African forests.Soils Ecosystems 7(2), $208-217$.

Hunter, H. and Walton, R. (2008) Land use effects on fluxes of suspended sediment, nitrogen and phosphorus from a river catchment, of the Great Barrier Reef, Australia.Journal of Hydrology, 356, 131-146.

Hsu, P., et al. (2007) Seasonal variation of sediment toxicity in the River Dommel and Elbe. Environ. Pollution 450-451, 25-35.

Kiteca, U. and Jain, S. (2005) River discharge sediment transport and exchange in Tana Estuarine. Coastal and Shelf Science, $63,455-465$.

McDowell, R.W., et al. (2004) Connecting phosphorus loss from agricultural landscapes to surface water quality. Chemistry and Ecology 20, 1-40.

Mitchell, C. et al. (2005) Sediment, nutrients and pesticide residues in event flow conditions in streams of the Mackay Whitsunday region, Australia.Marine Pollution Bulletin, 51, 23-36.

Rickson, R.J. (2014) Can control of soil erosion mitigate water pollution by sediments? Sci. Total Environment $1187-1197$.

Somura, H. et al. (2012) Impact of suspended sediment and nutrient loading from land uses against water quality in the Hii River basin, Japan. Journal of Hydrology, 450-451, 2-35.

Walling, D.E. (2005) Tracing suspended sediment sources in catchments and river systems. Sci. Total Environment 344, $159-184$.

Walling, D.E and Collins, A.L. (2008) The catchment sediment budget as a management tool. Environmental Science and Policy, 11, 136-143.

Zhang, Z. et al. (2007) Nutrient runoff from forested watersheds in Central Japan during typhoon floods, implications for understanding runoff mechanisms during flood events. Hydrological Processes 21, 1167-1178. 